\title{
Culturability of Clostridium botulinum Spores under Different Gemination Conditions, Sublethal Heat Treatments, and in the Presence of Nisin
}

\author{
Yoon-Kyung Chung ${ }^{\dagger}$ and Ahmed E. Yousef \\ Department of Food Science and Technology, The Ohio State University, Columbus, Ohio 43210-1007, USA
}

\begin{abstract}
Themal resistance and heat activation characteristics of Clostridium botulinum ATCC 25763 spores were evaluated. The effects of nisin and $\mathrm{pH}$ on the activation and subsequent gemination were also investigated. Spores of $C$. botulinum were not inactivated by heat treatments up to $92^{\circ} \mathrm{C}$ for $2 \mathrm{hr}$. Heat treatment at $85^{\circ} \mathrm{C}$ for 90 min was selected as the optimal activation condition based on monitoning subsequent gemination. L-alanine alone or in combination with L-cysteine was not sufficient to geminate the spores of this strain. Tryptone-PeptoneGlucose-Yeast extract (TPGY) broth supplemented with L-alanine was used as a suitable gemination medium. Decreasing $\mathrm{pH}$ of activation suspension increased the degree of phase darkening, i.e., gemination. In addition, the presence of nisin during activation increased the degree of phase darkening. The majority of spore populations were domant at a $\mathrm{pH}$ of less than 2.8 , and these populations required heat activation to increase the culturability on TPGY agar medium. However, extended heating in the presence of nisin at $\mathbf{p H} 2.8$ decreased the spore count; however, heat activation was less necessary at $\mathrm{pH} 3.4$, compared at $\mathrm{pH} 2.8$.
\end{abstract}

Key words: Clostridium botulinum, spore culturability, germination, nisin

\section{INTRODUCTION}

Spores can remain in a viable dormant state for extremely long periods of time. It is still not understood clearly how the spores are able to remain dormant for such long periods of time; nor has the initial trigger for breaking their dormancy been identified. This lack of understanding is of particular concern for the food industry because it requires harsh processing conditions to ensure that any spores are destroyed. A better understanding of the spore germination will help to develop novel milder processing conditions while maintaining microbiological safety. However, spore populations vary in the degree of dormancy, with some being more dormant than others. Typical levels of germination for the Bacillus subtilis PSB 357 strain was reported as approximately $50 \%$ (1). These researchers stated that this spore strain is generally assumed to have a high proportion of what are referred to as 'super dormant' spores. This explains the difficulties in using germination as a reliable control method for spores (2). Therefore, maximizing attempts for the activation of dormant spore population and subsequent germination is critical for controlling spores.

Activation describes changes in spores, which has been subjected to various pretreatments that alter the rate and extent of germination (3). Activation is most com- monly achieved by sublethal heat treatment, although several other treatments, such as extremes of $\mathrm{pH}$, reducing agents, $\mathrm{CaCl}_{2}$, and ethanol, have been used (4-9). Heat activation results in an increased extent of germination as well as simplification of the requirements for the initiation of germination. However, when the heat treatment is not carefully controlled, low spore counts will be obtained due to inadequate heat activation or excessive spore destruction (8). Extreme dormancy can result in an apparent reduction in resistance while leaving most spore components undamaged and the spore thus potentially viable (10). It is therefore important to be able to predict the ability of the spores to survive heat treatment and the effect of environmental conditions on their subsequent growth in foods (11). This approach is especially important for pathogenic spores such as $C$. botulinum, and the development of improved practical control procedures is needed.

One possible method for enhancing the effectiveness of thermal processes while using less severe heat treatments is through the addition of a bacteriocin such as nisin to lower the thermal resistance of bacterial spores so that survivors of nisin treatment will be more susceptible to thermal processes. Therefore, this study was conducted to investigate the optimal heat activation conditions of $C$. botulinum Type A spores. In addition, the effect of nisin and $\mathrm{pH}$ during heat activation of spores

${ }^{\dagger}$ Corresponding author. E-mail: Chung.115@osu.edu

Phone: +1-614-247-6831, Fax: +1-614-292-0218 
was examined.

\section{MATERIALS AND METHODS}

\section{Bacterial strains and preparation of spore suspensions}

Proteolytic C. botulinum Type A ATCC 25763 was obtained from the American Type Culture Collection (Manassas, VA). Culture was grown in TryptonePeptone-Glucose-Yeast extract (TPGY) broth and kept frozen at $-80^{\circ} \mathrm{C}$ with $40 \%(\mathrm{v} / \mathrm{v})$ sterile glycerol added to the broth. Spores of C. botulinum were formed on the surface of TPGY agar plate. Overnight culture was spread onto TPGY agar and incubated at $37^{\circ} \mathrm{C}$ in an anaerobic chamber for 7 10 days until more than $90 \%$ of population was sporulated. Spores were harvested by adding $10 \mathrm{~mL}$ of sterile cold deionized water, releasing the colonies containing spores from the surface of the agar with the use of a sterile disposable inoculating loop. Spores were collected by centrifugation at $4,000 \times g$ for $10 \mathrm{~min}$ at $4^{\circ} \mathrm{C}$ and the pellet was washed in sterile cold deionized water, and centrifuged again at $10,000 \times g$ for $10 \mathrm{~min}$ at $4^{\circ} \mathrm{C}$. Spore suspensions were then enzymatically cleaned by the methods of Billon et al. (12). The cleaning process consisted of aseptically treating each pellet with $100 \mathrm{~mL}$ of lysozyme solution $(200 \mu \mathrm{g} / \mathrm{mL}$ of lysozyme in $0.05 \mathrm{M}$ potassium phosphate buffer $\left[\mathrm{KH}_{2} \mathrm{PO}_{4}\right.$ and $\left.\mathrm{K}_{2} \mathrm{HPO}_{4}\right], \mathrm{pH} 8.1$ ) for $30 \mathrm{~min}$ at $45^{\circ} \mathrm{C}$. Then $100 \mathrm{~mL}$ trypsin solution $(100 \mu \mathrm{g} / \mathrm{mL}$ trypsin in $0.05 \mathrm{M}$ potassium phosphate buffer $\left[\mathrm{KH}_{2} \mathrm{PO}_{4}\right.$ and $\left.\mathrm{K}_{2} \mathrm{HPO}_{4}\right]$, $\mathrm{pH}$ 8.1) was added and the mixture was incubated for $2 \mathrm{hr}$ at $45^{\circ} \mathrm{C}$. Spore crops, then, were washed ten times in sterile deionized water by centrifugation at $10,000 \times g$ for $10 \mathrm{~min}$ at $4^{\circ} \mathrm{C}$. The final pellets were resuspended in sterile cold deionized water and kept refrigerated. Microscopic observations were made to confirm the purity of spore suspensions.

\section{Gemmination media}

Various germination buffers were tested to determine which germinants were needed for C. botulinum ATCC 25763 spores. Two germination buffers were used: citrate-phosphate buffer at $\mathrm{pH} 7$ or 2-( $\mathrm{N}$-morpholino)-ethanesulfonate (MES) buffer at $\mathrm{pH}$ 6. Germinants such as
L-alanine $(100 \mathrm{mM}$ or $200 \mathrm{mM})$ and/or L-cysteine $(50$ $\mathrm{mM}$ ) were also included in the germination buffer. In addition, TPGY broth containing $200 \mathrm{mM} \mathrm{L}$-alanine was tested as a germination medium. Germination media are listed in Table 1. Spore suspension (containing approximately $10^{7}$ spores $/ \mathrm{mL}$ in deionized water) was dispensed in each 200- $\mu \mathrm{L}$ thin wall microtest tubes (Biorad Laboratories, Hercules, CA) and submerged and heated at $80^{\circ} \mathrm{C}$ for $15 \min (13,14)$ in a circulating water bath (Haake, Germany). Activated spores were transferred into the anaerobic chamber, added into the different germination buffers, and incubated at $37^{\circ} \mathrm{C}$ for germination. Samples of spore-buffer mixture were taken periodically, and phase-change of the spores in germination medium was examined under a phase-contrast microscope (Bausch and Lomb, Rochester, NY). The numbers of phase-bright (ungerminated) spores and phase-dark (germinated) spores were counted.

\section{Measuring degree of gemmination}

Spore germination was measured by determining loss of heat resistance and observing phase darkening of spores. For monitoring germination, spore suspensions were heat activated at various temperatures, and then transferred to the germination buffer inside the anaerobic chamber. Spores in germination buffer were incubated at $37^{\circ} \mathrm{C}$, and aliquots were withdrawn at predetermined intervals. Aliquots were spread-plated in TPGY agar without reheating, or heated at $80^{\circ} \mathrm{C}$ for $30 \mathrm{~min}$ and surviving spores were enumerated using TPGY agar medium. Samples of the incubated mixture were also examined by phase-contrast microscopy (Bausch and Lomb, Rochester, NY) at a magnification of 1,000X. The numbers of phase-bright (ungerminated) spores and phase-dark (germinated) spores were counted. All media and reagents were prepared at least $24 \mathrm{hr}$ before use and kept at $22 \sim 25^{\circ} \mathrm{C}$ in the anaerobic chamber (15).

\section{Optimal heat activation treatment}

The heat resistance was assayed at various temperatures ranging from 80 to $100^{\circ} \mathrm{C}$ to investigate the lethal and sublethal temperatures for C. botulinum ATCC 25763 spores. Aliquots of $200 \mu \mathrm{L}$ (containing approx-

Table 1. Media used in this study for germination of Clostridium botulinum spores

\begin{tabular}{lllc}
\hline Germination medium & $\mathrm{pH}$ & Concentration of germinant & Reference \\
\hline Citrate-phosphate buffer & 7.0 & $100 \mathrm{mM}$ L-alanine & 13,14 \\
& & $200 \mathrm{mM}$ L-alanine & 25 \\
MES buffer ${ }^{1)}$ & 6.1 & $100 \mathrm{mM}$ L-alanine + $50 \mathrm{mM}$ L-cysteine & 15 \\
TPGY broth $^{2)}$ & 6.8 & $100 \mathrm{mM}$ L-alanine + 50 mM L-cysteine & \\
\hline
\end{tabular}

\footnotetext{
${ }^{1)}$ MES: 2-(N-morpholino)-ethanesulfonate. ${ }^{2)}$ TPGY: Tryptone-Peptone-Glucose-Yeast extract.
} 
imately $10^{7}$ spores $/ \mathrm{mL}$ in deionized water) were dispensed in $200 \mu \mathrm{L}$ thin wall microtest tubes (Biorad Laboratories, Hercules, CA) and submerged and heated in a circulating water bath (Haake, Germany). Each sample tube was withdrawn at predetermined intervals, kept on ice, and then transferred into the anaerobic chamber. Spore suspensions were serially diluted in $0.1 \%$ peptone water and were enumerated in TPGY agar after incubation at $37^{\circ} \mathrm{C}$ for $24 \sim 48 \mathrm{hr}$ under anaerobic conditions.

Heat treatments at selected sublethal temperatures were compared for their ability to enhance spore germination. Variable heating periods, i.e., 15, 30, 45, 60, or $90 \mathrm{~min}$, at three different temperatures, i.e., 80,85 , or $90^{\circ} \mathrm{C}$, were selected and germination was monitored by the methods described earlier.

\section{Spore gemmination in different nisin preparations}

Nisaplin $\left(10^{6} \mathrm{IU}\right.$ of nisin/g), a commercial nisin concentrate composed of $2.5 \%$ nisin in denatured milk solids and sodium chloride, or pure nisin was obtained from Alpine and Barrette Ltd. (Trowbridge, UK). Stock solutions of nisin containing $10^{5} \mathrm{IU} / \mathrm{mL}$ in $0.02 \mathrm{~N} \mathrm{HCl}$ was prepared as described by Scott and Taylor (16). The $\mathrm{pH}$ was adjusted to $2 \sim 3$ with $\mathrm{HCl}$ solution and the mixture was autoclaved $\left(10 \mathrm{~min}\right.$ at $\left.121^{\circ} \mathrm{C}\right)$ and stored at $4^{\circ} \mathrm{C}$.

Different nisin preparations (Nisaplin or pure nisin) were added to the spore suspension to achieve a concentration of $250 \mu \mathrm{g} / \mathrm{mL}$. The addition of nisin preparation lowered the $\mathrm{pH}$ of the activation medium (i.e., mixture of nisin stock solution and spores in deionized water), since the $\mathrm{pHs}$ of stock solutions of nisin preparations

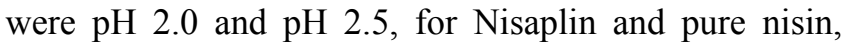
respectively. Thus, resulting $\mathrm{pH}$ values of activation medium were 2.8 and 3.4 for Nisaplin and pure nisin-containing solution, respectively. The $\mathrm{pH}$ value of the spore suspension without nisin preparation was 4.9. Peptone water adjusted $\mathrm{pH}$ to 2.8 and 3.4 was used as control, to differentiate the effect of $\mathrm{pH}$ and nisin. Different heat activation treatments, in the absence or presence of nisin, under two pHs (2.8 and 3.4), were applied as follows: (i) no heat; (ii) heating at $85^{\circ} \mathrm{C}$ for $30 \mathrm{~min}$; (iii) heating at $85^{\circ} \mathrm{C}$ for $90 \mathrm{~min}$; (iv) heating at $85^{\circ} \mathrm{C}$ for $90 \mathrm{~min}$, followed by $5 \mathrm{~min}$ of cooling, then reheating at $80^{\circ} \mathrm{C}$ for $30 \mathrm{~min}$, and enumerated cultivable spores on TPGY agar. Phase change of spores was also examined before and after heat activation treatment in the presence of nisin.

\section{RESULTS AND DISCUSSION}

\section{Gemination media}

Different media were compared for their capabilities for germinating C. botulinum spores (Table 1). Examination of phase change of spores showed that germination occurred in TPGY broth, but not in other buffer media in the presence of germinant (Data not shown). After heat activation at $80^{\circ} \mathrm{C}$ for $15 \mathrm{~min}$, spores in the buffer media containing L-alanine and/or L-cysteine remained phase-bright (ungerminated) after incubating at $37^{\circ} \mathrm{C}$ overnight (Data not shown). Therefore, L-alanine alone or in combination with L-cysteine was not sufficient to induce spore germination. It is apparent that ingredient(s) in TPGY broth aided germination, but this was not investigated in this study. Pol et al. (17) also observed similar results with Bacillus cereus spores. These researchers monitored the germination process in BHI broth and HEPES buffer containing L-alanine $(10 \mathrm{mM})$ as a germinant. Only $35 \%$ of the spores germinated in HEPES buffer containing L-alanine, while more than $95 \%$ of the spores germinated in BHI broth.

Generally, the germination requirement of Clostridium species is complex, requiring a combination of several ingredients, compared to Bacillus species, in which a single compound, e.g. L-alanine, often initiates germination. Germination of spores of proteolytic C. botulinum type A and B (strains 62A, 190, B-aphis, Ba410, Beans) was triggered by a defined three-component mixture comprising L-alanine (or L-cysteine)/L-lactate (or sodium thioglycollate)/ sodium bicarbonate in buffer at a neutral $\mathrm{pH}$ (18-20). Similarly, optimum germination of spores of non-proteolytic C. botulinum types B, E, $\mathrm{F}$ occurred in L-alanine/L-lactate, L-cysteine/L-lactate, and L-serine/L-lactate containing phosphate buffer (21). Uehara and Frank (22) also found that germination of spores of C. sporogenes PA 3679h was stimulated by thioglycollate $(0.1 \%)$ in L-alanine + pyrophosphate system, in which the two latter components were essential. Amino acids alone did not stimulate the germination of spores of $C$. bifermentans, and the minimum requirement of compounds needed for the germination was the presence of L-alanine, L-phenylalanine and lactate (23). In addition, an unknown factor present in yeast extract was suggested for enhanced germination (23). Treadwell et al. (24) also indicated that yeast extract and sodium bicarbonate were necessary for rapid germination of $C$. botulinum $62 \mathrm{~A}$ spores. Therefore, it is also probable that some ingredient(s) in the yeast extract, included in TPGY agar, was essential for the germination of C. botulinum spores used in our study.

In conclusion, evidence from previous studies suggests that L-alanine is essential for the germination of clostridial spores, however, additional germinants were also required for enhanced germination. Therefore, TPGY 


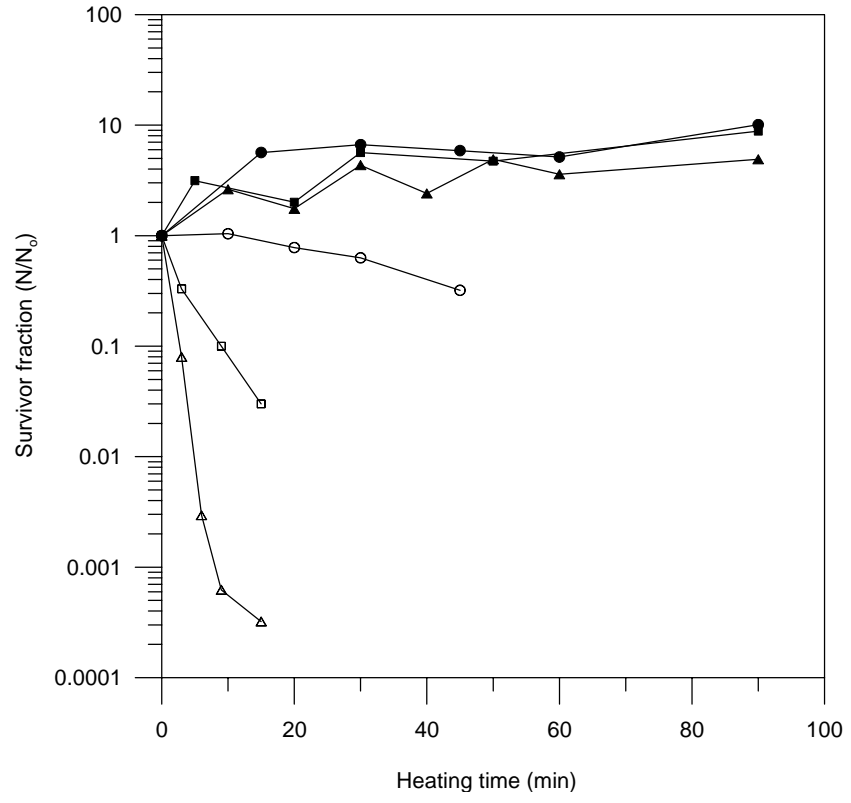

Fig. 1. Representative survivor curves for Clostridium botulinum ATCC 25763 spores suspended in deionized water. (•)

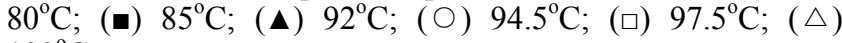
$100^{\circ} \mathrm{C}$

broth supplemented with L-alanine $(200 \mathrm{mM})$ was selected as the germination medium for the strain used in this study.

\section{Optimal heat activation treatment}

To determine optimal activation treatment, spores of C. botulinum were heated at $80^{\circ} \mathrm{C}$ to $100^{\circ} \mathrm{C}$ for up to $90 \mathrm{~min}$. Culturable spore population of this strain were not decreased by heat treatments up to $92^{\circ} \mathrm{C}$ for $90 \mathrm{~min}$; actually, culturability increased with extended heating (Fig. 1). This indicates that considerable activation occurred and inactivation did not occur during $90 \mathrm{~min}$ heating at $80 \sim 92^{\circ} \mathrm{C}$. Different sublethal heating treatments, $80^{\circ} \mathrm{C}$ for $15 \mathrm{~min}, 85^{\circ} \mathrm{C}$ for $15 \mathrm{~min}$, and $85^{\circ} \mathrm{C}$ for $90 \mathrm{~min}$, were compared for optimal activation and subsequent germination. Loss of heat resistance was not observed during $3 \mathrm{hr}$ period of germination incubation at $37^{\circ} \mathrm{C}$ after heat activation at $80^{\circ} \mathrm{C}$ for $15 \mathrm{~min}$, and the counts of heat-treated samples were even higher than control samples (Fig. 2a). These results suggest that heat activation at $80^{\circ} \mathrm{C}$ for $15 \mathrm{~min}$ did not fully activate the spores, so the spores did not germinate readily, and further activation, which occurred during reheating $\left(80^{\circ} \mathrm{C}\right.$ for $\left.30 \mathrm{~min}\right)$, increased the count. Generally, heat activation treatment at $80^{\circ} \mathrm{C}$ for $10 \sim 15 \mathrm{~min}$ is used for the proteolytic clostridial spores in most other studies $(13,15,25,26)$. However, this treatment was not sufficient to activate the spores of this strain. Therefore, a higher degree of heat treatment was tested. Heat treatments for 15 and $90 \mathrm{~min}$ at $85^{\circ} \mathrm{C}$ increased heat sensitivity of
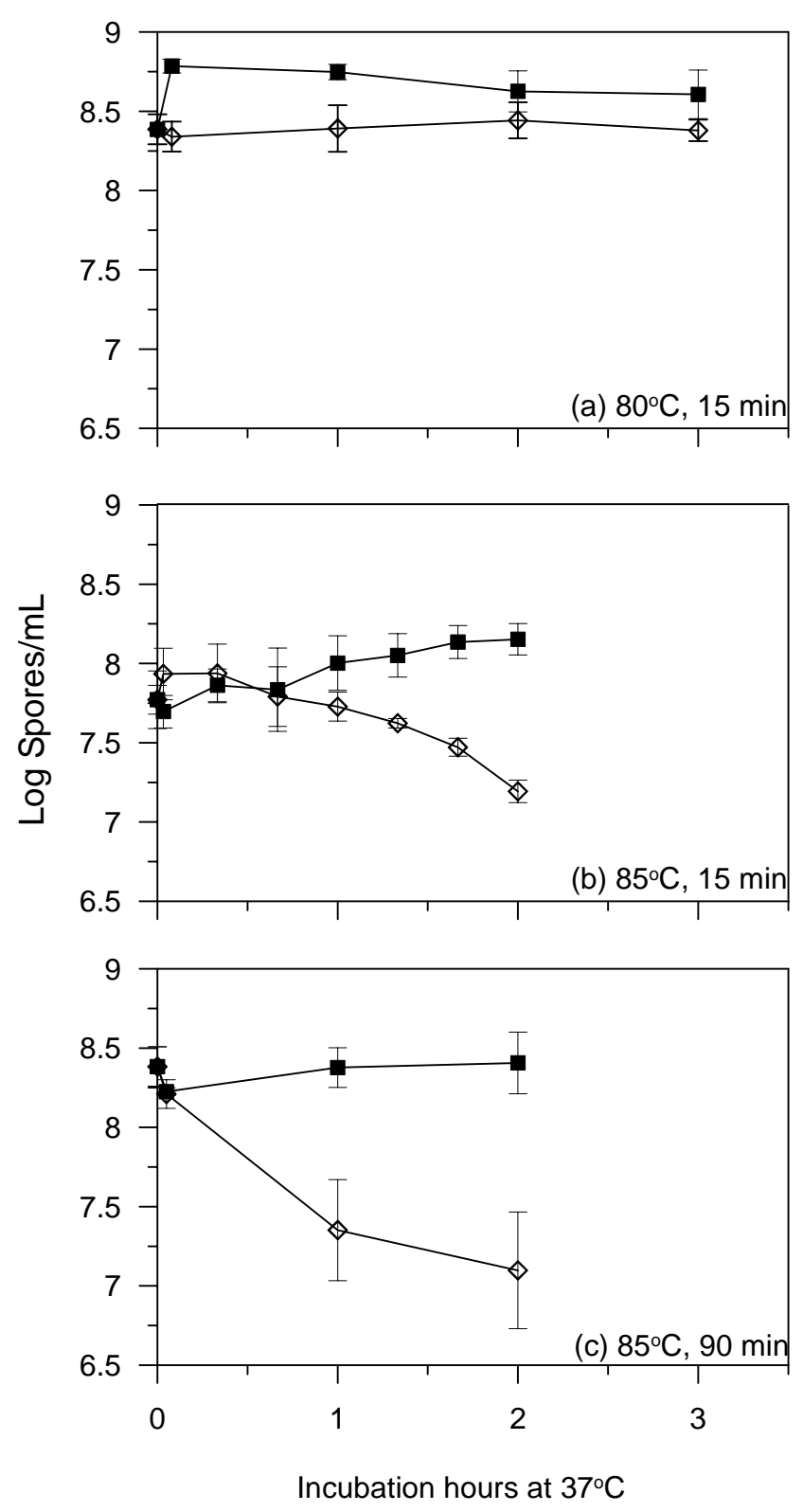

Fig. 2. Monitoring germination of $C$. botulinum spores. Spore suspension was heat activated at (a) $80^{\circ} \mathrm{C}$ for $15 \mathrm{~min}$, (b) $85^{\circ} \mathrm{C}$ for $15 \mathrm{~min}$, or (c) $85^{\circ} \mathrm{C}$ for $90 \mathrm{~min}$, incubated at $37^{\circ} \mathrm{C}$ in the presence of germinant. Samples were taken at intervals, reheated at $80^{\circ} \mathrm{C}$ for $30 \mathrm{~min}$ and culturable spores were counted on TPGY agar. Non-reheated spores were also plated as a control treatment. Heat activation treatment: ( $\square)$ no heating (control); $(\diamond)$ reheating at $80^{\circ} \mathrm{C}$ for $30 \mathrm{~min}$ during sampling.

spores, spore counts decreased as the germination proceeded (Fig. $2 \mathrm{~b} \&$ 2c). Germination occurred more readily after heating for $90 \mathrm{~min}$ at $85^{\circ} \mathrm{C}$ than for $15 \mathrm{~min}$ heating. In addition, the effect of intermittent heating on the culturability of spore was examined after these three heat activation treatments (Fig. 3). Culturability was increased after all three heat activation (pre-heating) treatments, compared to non-heated spores. Reheating for $30 \mathrm{~min}$ at $80^{\circ} \mathrm{C}$ further increased the culturability 


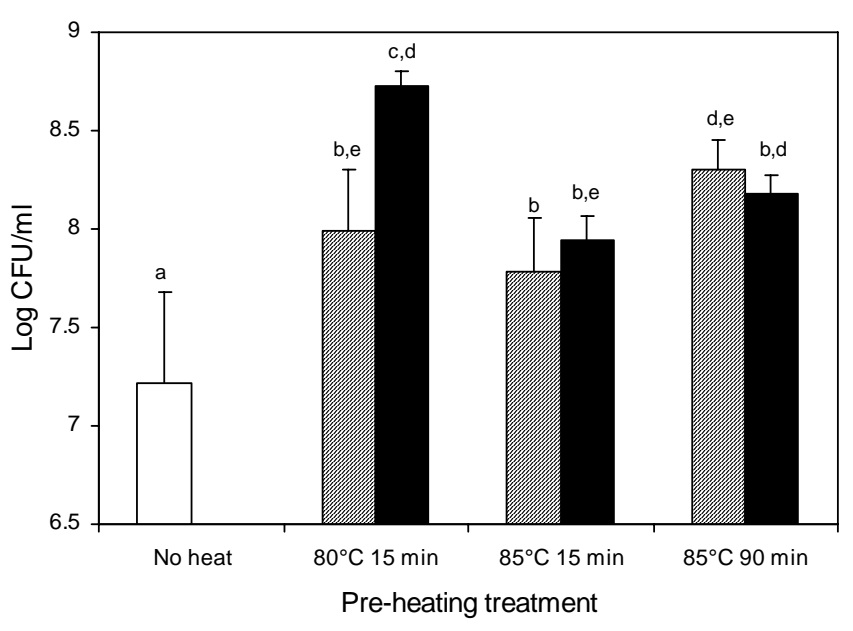

Fig. 3. Activation of $C$. botulinum spores by intermittent heating. Spore suspension was pre-heated at $80 \sim 85^{\circ} \mathrm{C}$ for 1 5 90 min and then reheated at $80^{\circ} \mathrm{C}$ for $30 \mathrm{~min}$. (口) no pre-heating; (ख) pre-heated only; ( $\mathbf{\square})$ pre-heated and reheated. Bars denoted by different letters indicate significant $(\alpha=0.05)$ differences as measured by ANOVA.

of spore samples, which were activated at $80^{\circ} \mathrm{C}$ for 15 $\min$ and $85^{\circ} \mathrm{C}$ for $15 \mathrm{~min}$. The effect of double heating was greater with the lower degree of pre-heating treatment $\left(80^{\circ} \mathrm{C}\right.$ for $\left.15 \mathrm{~min}\right)$, than $85^{\circ} \mathrm{C}$ for $15 \mathrm{~min}$. This suggested that double-stage, intermittent heating with mild temperatures was very effective to increase the culturability (i.e., germinated population on the agar medium) of spores. The spore count after double-heating (pre-heated at $80^{\circ} \mathrm{C}$ for $15 \mathrm{~min}$, and reheated at $80^{\circ} \mathrm{C}$ for $30 \mathrm{~min}$ ), was comparable to the count obtained after single-heating at $85^{\circ} \mathrm{C}$ for $90 \mathrm{~min}$. Cho et al. (27) also found that double-stage heating at lethal temperatures inactivated $B$. subtilis spores more effectively as compared to the single-stage heating, indicating intermittent heating effectively increased the degree of activation. On the other hand, reheating did not increase the culturability of spores, which was heat activated at $85^{\circ} \mathrm{C}$ for $90 \mathrm{~min}$ (Fig. 3). Therefore, treatment at $85^{\circ} \mathrm{C}$ for 90 min was sufficient to activate the spore populations fully. In other words, the best activation was achieved with a single heating treatment at this condition.

Phase contrast microscopy observation also showed similar results. Heating at $85^{\circ} \mathrm{C}$ for 90 min produced the greatest degree of phase change of spores, compared to the other heat activation treatments (Fig. 4). At $80^{\circ} \mathrm{C}$, even for an extended period $(90 \mathrm{~min})$ of heating (single-stage heating), did not activate most of the spore population (Fig. 4a). Thus, less than $20 \%$ of spores were phase-darkened after $2 \mathrm{hr}$ germination incubation. On the other hand, at $85^{\circ} \mathrm{C}$ and $90^{\circ} \mathrm{C}$, the degree of germination increased in proportion to the heating time at each temperature (Fig. 4b \& 4c). However, in general, germination occurred more readily in samples treated at $85^{\circ} \mathrm{C}$ than $90^{\circ} \mathrm{C}$. Therefore, activation treatment at $85^{\circ} \mathrm{C}$ for 90 min was chosen for C. botulinum strain used in this study. Earlier studies indicated that the temperature and duration of heating for optimal activation of spores vary widely among different species and even among different spore preparations of the same strain (28). Gibbs (23) also reported that spores of $C$. bifermentans germinated readily after heat activation at $80 \sim 90^{\circ} \mathrm{C}$ (optimal at $85^{\circ} \mathrm{C}$ ), but heating at temperatures $\leq 70^{\circ} \mathrm{C}$ or $\geq 90^{\circ} \mathrm{C}$ pre-
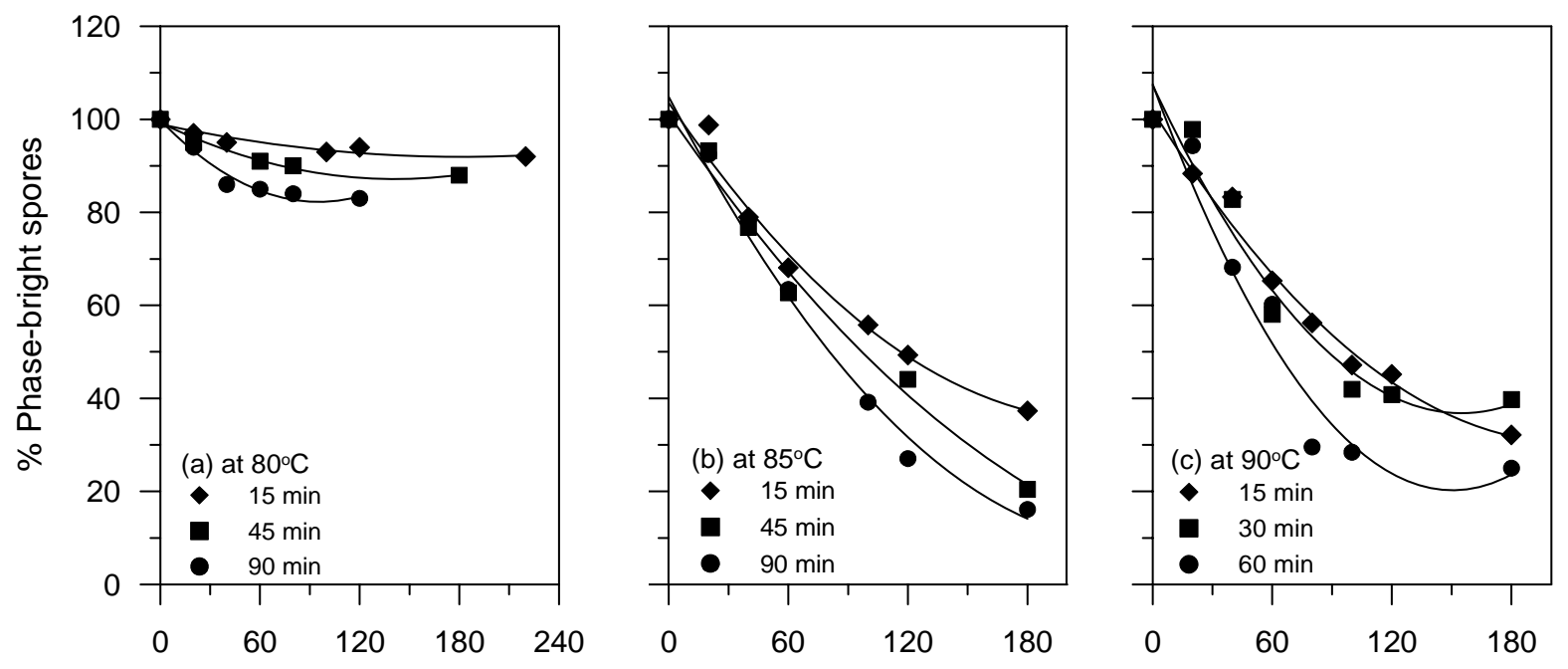

Time (minutes)

Fig. 4. Monitoring germination of $C$. botulinum spores by phase change observation. Spore suspension was heat activated at 80,85 , or $90^{\circ} \mathrm{C}$ for $15 \sim 90 \mathrm{~min}$, and incubated at $37^{\circ} \mathrm{C}$ in the germination medium. Samples were examined under phase-contrast microscope at intervals. 
vented subsequent germination.

\section{Spore gemmination in different nisin preparations}

Culturability of control samples (no nisin added) during activation at $\mathrm{pH}$ values of 2.8 and 3.4 was compared. Lower $\mathrm{pH}$ (2.8) suppressed the activation by heat (Fig. $5)$. In other words, heat activation treatment was necessary to increase the spore culturability under lower $\mathrm{pH}$ conditions. In addition, at $\mathrm{pH} 2.8$, culturability was increased in proportion to the heating duration. At $\mathrm{pH} 2.8$, similar spore counts on agar plates, as the counts obtained from control samples under $\mathrm{pH} 3.4$, could be obtained only after double-stage, intermittent heating $\left(85^{\circ} \mathrm{C}\right.$ for $90 \mathrm{~min}+80^{\circ} \mathrm{C}$ for $30 \mathrm{~min}$ ). On the other hand, there was no measurable increase in spore culturability after heat treatments at $\mathrm{pH} 3.4$. Thus, the majority of spore populations (more than $90 \%$ of maximum spore count)

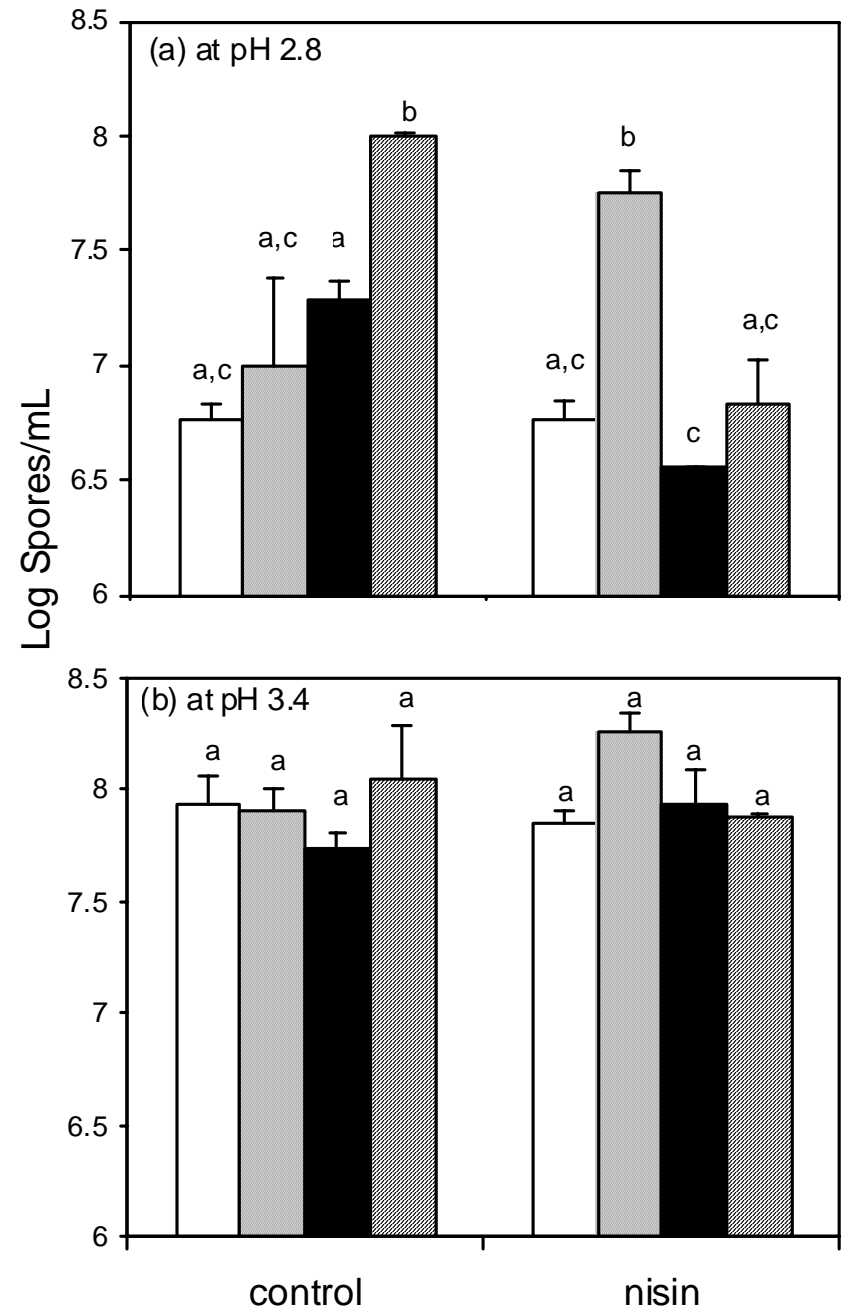

Fig. 5. Culturability of $C$. botulinum spores after heating at two different $\mathrm{pH}$ values and in the presence or absence of nisin $(250 \mu \mathrm{g} / \mathrm{mL})$. ( $\square)$ no heat; (圆) heated at $85^{\circ} \mathrm{C}$ for 30 min; (ם) heated at $85^{\circ} \mathrm{C}$ for $90 \mathrm{~min}$; ( $\left.\square\right)$ heated at $85^{\circ} \mathrm{C}$ for $90 \mathrm{~min}+$ reheated at $80^{\circ} \mathrm{C} 30 \mathrm{~min}$. were dormant at a lower $\mathrm{pH}(\mathrm{pH} 2.8)$, and these populations required heat activation treatment to germinate on the nutrient medium.

On the other hand, presence of nisin decreased the heat activation requirement for the spores under low $\mathrm{pH}$. In other words, short time, single-stage heating in the presence of nisin resulted in a similar degree of culturability as in spores treated with double-stage heating in the absence of nisin. However, extended heating at $\mathrm{pH}$ 2.8 in the presence of nisin decreased spore culturability. Steinbuch (7) also found that heat activation in acidic condition resulted in destruction of spores during the heat treatment. Activation of $B$. stearothermophilus spores in a suspension of $\mathrm{pH} 3.5$ for $20 \mathrm{~min}$ at $100^{\circ} \mathrm{C}$ caused no destruction, however, intensification of heat activation to $15 \mathrm{~min}$ at $105^{\circ} \mathrm{C}$ or $10 \mathrm{~min}$ at $110^{\circ} \mathrm{C}$, decreased spore counts by 1.5 and 3 logs, respectively (7). Beard et al. (29) reported that D-values of B. licheniformis spores were lower in the presence of nisin and this effect of nisin was further enhanced under lower $\mathrm{pH}$.

High acidity during heat activation treatment increased the degree of phase darkening of spores, and nisin enhanced it synergistically (Fig. 6). Different $\mathrm{pH}$ of the heating suspension during activation at $85^{\circ} \mathrm{C}$ for $90 \mathrm{~min}$ affected phase-change of spores. Initially, \% phase-dark spores in three different $\mathrm{pH}$ suspensions before heat activation were between $5 \sim 7 \%$. After heat activation, lower $\mathrm{pH}$ (pH 2.8) enhanced phase darkening of spores, compared to higher $\mathrm{pH}$ values $(\mathrm{pH} 3.4$ and 4.9). Heat activation in a suspension at $\mathrm{pH} 2.8$ induced phase darkening to $17 \sim 18 \%$ of the spore population. Under similar $\mathrm{pH}$ values, degree of phase darkening was greater in the presence of nisin than its absence (Fig. 6). In addition,

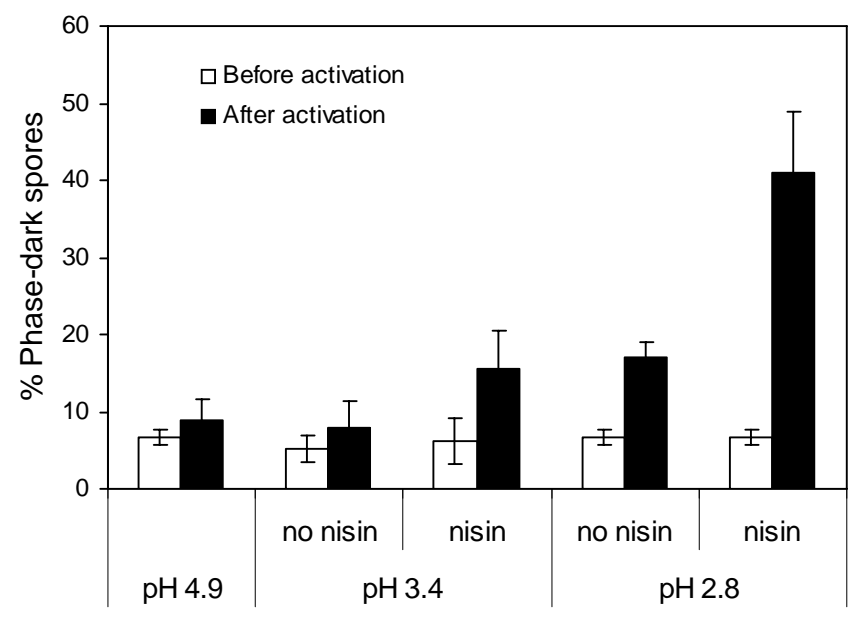

Fig. 6. Phase-change observation of $C$. botulinum spores before and after heat activation treatment (at $85^{\circ} \mathrm{C}$ for $90 \mathrm{~min}$ ). Different activation conditions were compared under different $\mathrm{pHs}$ and in the presence or absence of nisin $(250 \mu \mathrm{g} / \mathrm{mL})$. 
$\%$ phase-dark spores were higher $(40 \%)$ when spores were activated at low $\mathrm{pH}(\mathrm{pH} 2.8)$ in the presence of nisin, than in suspension at $\mathrm{pH} 3.4(15 \%)$ in the presence of nisin (Fig. 6). Keynan et al. (28) also indicated that incubation of $B$. cereus spores in the presence of a reducing agent such as mercaptoethanol or thioglycollate or under low $\mathrm{pH}$ (less than 4.5) resulted in a partial activation of spores. Even though the incubation with reducing agents or under low $\mathrm{pH}$ did not replace the heat activation completely, it increased the germination rate considerably compared to unheated samples (28). Therefore, nisin and/or acidic environment activated spores, and furthermore some populations were germinated, by observing phase-darkening, without the addition of germinants.

It has been reported that nisin activity is directly related to the presence of dehydroalanine residues, which can readily react with sulfhydryl groups $(30,31)$. Spore coats mainly consist of spore proteins, which contain high amount of cysteine (32), and it is likely that a coat protein rich in cysteine, stabilized by S-S linkages, is responsible for maintaining the dormant state (28). Therefore, the effect of nisin and $\mathrm{pH}$ on the activation of spores could be related to the reduction of disulfide bonds in spore protein. Hashimoto and Conti (33) observed the comb-like structures in the spore coat in heat-activated $B$. cereus spores. Their study indicated that these comb-like structures might represent cysteine-rich structural protein present in the spore coat and the rapid disappearance of this subcoat space occurred concomitantly with the loss of heat resistance. Srivastava and Fitz-James (34) also reported that heat activation $\left(70^{\circ} \mathrm{C}\right.$ for $\left.20 \mathrm{~min}\right)$ resulted in alteration in structural proteins and enzymes found in $B$. cereus spore coats. These researchers observed the changes, such as increased glycosylation of coat proteins, alteration in polypeptide patterns on sodium dodecyl sulfate-polyacylamide gels, and an increase in free SH groups of proteins. All of these studies suggested that spore coat or spore coat proteins are the possible targets for activation of germination by reducing agent, heat or $\mathrm{pH}$.

\section{ACKNOWLEDGEMENTS}

The authors acknowledge The Center for Advanced Processing and Packaging Studies (Raleigh, North Carolina) for funding this research. We also appreciate Dr. Jin-Gab Kim for his technical assistance.

\section{REFERENCES}

1. Ablett S, Darke AH, Lillford PJ, Martin DR. 1999. Glass formation and dormancy in bacterial spores. Int $J$ Food Sci Technol 34: 59-69.

2. Gould GW, Jones A, Wrighton C. 1968. Limitations of the initiation of germination of bacterial spores as a spore control procedure. J Appl Bacteriol 31: 357-366.

3. Lefebvre GM, Leblanc R. 1988. The kinetics of change in bacterial spore germination. In Physiological Models in Microbiology. Bazin MJ, Prosser JI, eds. CRC Press, Boca Raton, Florida. Vol II.

4. Gibbs PA. 1967. The activation of spores of Clostridium bifermentans. J Gen Microbiol 46: 285-291.

5. Keynan A, Evenchik Z. 1969. Activation. In The Bacterial Spore. Gould GW, Hurst A, eds. Academic Press, London. p 359-395.

6. Issahary G, Evenchik Z, Keynan A. 1970. Low-pH activation of Bacillus cereus spores. J Bacteriol 101: 418-423.

7. Steinbuch E. 1976. The acid sensitization of heat resistant bacterial spores. In Spore Research. Barker AN, Wolf J, Ellar DJ, Dring GI, Gould GW, eds. Academic Press, London. Vol II, p 451-468.

8. El-Mabsout YE, Stevenson KE. 1979. Activation of Bacillus stearothermophilus spores at low pH. J Food Sci 44: 705-709.

9. Kim J, Foegeding PM. 1990. Effects of heat-, $\mathrm{CaCl}_{2-}$, and ethanol-treatments on activation of Bacillus spores. J Appl Bacteriol 69: 414-420.

10. Gould GW. 1985. Modification of resistance and dormancy. FEMS Symposium 18: 371-382.

11. Laurent Y, Arino S, Rosso L. 1999. A quantitative approach for studying the effect of heat treatment conditions on resistance and recovery of Bacillus cereus spores. Int J Food Microbiol 48: 149-157.

12. Billon CMP, McKirgan CJ, McClure PJ, Adair C. 1997. The effect of temperature on the germination of single spores of Clostridium botulinum 62A. J Appl Microbiol 82: 48-56.

13. Chaibi A, Ababouch LH, Busta FF. 1996. Inhibition by monoglycerides of L-alanine-triggered Bacillus cereus and Clostridium botulinum spore germination and outgrowth. J Food Prot 59: 832-837.

14. Chaibi A, Ababouch LH, Belasri K, Boucetta S, Busta FF. 1997. Inhibition of germination and vegetative growth of Bacillus cereus $\mathrm{T}$ and Clostridium botulinum 62A spores by essential oils. Food Microbiol 14: 161-174.

15. Mazzotta AS, Montville TJ. 1999. Characterization of fatty acid composition, spore germination, and thermal resistance in a nisin-resistant mutant of Clostridium botulinum 169B and in the wild-type strain. Appl Environ Microbiol 65: $659-664$

16. Scott VN, Taylor SL. 1981. Effect of nisin on the outgrowth of Clostridium botulinum spores. J Food Sci 46: 117-120.

17. Pol IE, van Arendonk WGC, Mastwijk HC, Krommer J, Smid EJ, Moezelaar R. 2001. Sensitivities of germinating spores and carvacrol-adapted vegetative cells and spores of Bacillus cereus to nisin and pulsed-electric-field treatment. Appl Environ Microbiol 67: 1693-1699.

18. Rowley DB, Feeherry F. 1970. Conditions affecting germination of Clostridium botulinum 62A spores in a chemically defined medium. J Bacteriol 104: 1151-1157.

19. Montville TJ, Jones SB, Conway LK, Sapers GM. 1985. Germination of spores from Clostridium botulinum Baphis and Ba410. Appl Environ Microbiol 50: 795-800.

20. Broussolle V, Alberto F, Sherman CA, Mason DR, Botella 
L, Nguyen-The C, Peck MW, Carlin F. 2002. Molecular and physiological characterization of spore germination in Clostridium botulinum and C. sporogenes. Anaerobe 8: 89-100.

21. Plowman J, Peck MW. 2002. Use of a novel method to characterize the response of spores of non-proteolytic Clostridium botulinum types $\mathrm{B}, \mathrm{E}$, and $\mathrm{F}$ to a wide range of germinants and conditions. J Appl Microbiol 92: 681-694.

22. Uehara M, Frank HA. 1967. Sequence of events during germination of putrefactive anaerobe 3679 spores. $J$ Bacteriol 94: 506-511.

23. Gibbs PA. 1964. Factors affecting the germination of spores of Clostridium bifermentans. J Gen Microbiol 37: 41-48.

24. Treadwell PE, Jann GJ, Salle AJ. 1958. Studies on factors affecting the rapid germinations of spores of Clostridium botulinum. J Bacteriol 76: 549-556.

25. Blocher JC, Busta FF. 1985. Multiple modes of inhibition of spore germination and outgrowth by reduced $\mathrm{pH}$ and sorbate. J Appl Bacteriol 59: 469-478.

26. Okereke A, Montville TJ. 1991. Bacteriocin-mediated inhibition of Clostridium botulinum spores by lactic acid bacteria at refrigeration and abuse temperatures. Appl Environ Microbiol 57: 3423-3428.

27. Cho HY, Yousef AE, Sastry SK. 1999. Kinetics of in- activation of Bacillus subtilis spores by continuous or intermittent ohmic and conventional heating. Biotechnol Bioengineer 62: 368-372.

28. Keynan A, Evenchik Z, Halvorson HO, Hastings JW. 1964. Activation of bacterial endospores. J Bacteriol 88: 313-318.

29. Beard BM, Sheldon BW, Foegeding PM. 1999. Thermal resistance of bacterial spores in milk-based beverages supplemented with nisin. J Food Prot 62: 484-491.

30. Gross E, Morell JL. 1971. The presence of dehydroalanine in the antibiotic nisin and its relationship to activity. $J$ Amer Chem Soc 93: 4634-4635.

31. Liu W, Hansen JN. 1993. The antimicrobial effect of a structural variant of subtilin against outgrowing Bacillus cereus $\mathrm{T}$ spores and vegetative cells occurs by different mechanisms. Appl Environ Microbiol 59: 648-651.

32. Tipper DJ, Gauthier JJ. 1972. Structure of the bacterial endospore. In Spores V. Halvorson HO, Hansen R, Campnell LL, eds. American Society for Microbiology, Washington DC. p 3-12.

33. Hashimoto T, Conti SF. 1971. Ultrastructural changes associated with activation and germination of Bacillus cereus T spores. J Bacteriol 105: 361-368.

34. Srivastava OP, Fitz-James PC. 1981. Alteration by heat activation of enzymes localized in spore coats of Bacillus cereus. Can J Microbiol 27: 408-416.

(Received November 20, 2007; Accepted December 13, 2007) 